\title{
On the curriculum system construction of entrepreneurship education based on the perspective of general education
}

\author{
Wu Binying ${ }^{1, a}$, Ni Feng ${ }^{1, b}$, Wu Jinghui ${ }^{2, c}$ \\ ${ }^{1}$ Jiangxi Science \& Technology Normal University, Nanchang, Jiangxi, 330013, P.R. China \\ ${ }^{2}$ East China Model High School, Shanghai, 200040, P.R. China \\ aellen_wby@sina.com, b327369601@qq.com, ${ }^{\mathrm{c}} 2658402638 @ q q . c o m$
}

Keywords: General education, Entrepreneurship education, Curriculum system construction

\begin{abstract}
This article briefly describes the meaning of general education and the importance of entrepreneurship education curriculum, and discusses the construction of entrepreneurship education curriculum system in the perspective of general education, in order to provide some constructive suggestions for the construction of the curriculum system of entrepreneurship education.
\end{abstract}

\section{Introduction}

With the deepening reform of education, the higher education is becoming more and more popular, the employment of graduates becomes a big problem, it is important to improve the professional competence and innovation spirit. And entrepreneurship education curriculum, to change this phenomenon, it jumped out of the entrepreneurship to teach entrepreneurship the narrow field of vision, from the theoretical point of view, to explore a suitable road of entrepreneurship students, so that students can apply their knowledge, not to waste the learned knowledge. General education as a part of education is to provide students with knowledge and values among different groups in the context of multiple social backgrounds. In the perspective of general education, entrepreneurship education curriculum, people-oriented, so that the students can be fully developed, can adapt to the development of society.

\section{General education}

General education is a kind of teaching method which is beyond utility and practicality. It is a kind of teaching method that truly implement "democracy, science, freedom and tolerance". So that students can get rid of the curse, and can help students to choose the course. Cultivate their practical ability, application ability, innovation ability and thinking ability. Changed the traditional teaching methods, the unity and cooperation and inquiry learning method, to stimulate students interest in learning, as well as to cultivate the students' scientific research consciousness and the spirit of teamwork. More than that, the implementation of general education, not only improve the students' comprehensive ability, and the development of their unique personality, personal charm, and let them learn how to handle the method, not only do things well, in the process of interaction with people can also grasp a set of scale, in all aspects can get a good development.

\section{The importance of entrepreneurship education curriculum}

Since the reform and opening up, China's market economy continues to develop, the industrial structure is constantly adjusted, then change is the job. In today's college students, many students have the entrepreneurial impulse, but a lot of it is just think, not to do this thing. For "whether there is an entrepreneurial impulse", through the questionnaire survey, we get: $4 \%$ of people do not, $7 \%$ of people have ideas and have started to start a business, and $89 \%$ of people just stay in the stage of thinking. And the purpose of the business is also varied, some in order to achieve self value, some in order to make money, and some in order to escape the pressure of employment 
Regardless of what purpose, for the entrepreneur, is facing a lot of challenges. College Students' entrepreneurship has the support of national policies, but its serious lack of social experience, entrepreneurship is a social activity, lack of social experience will increase the difficulty of College Students' entrepreneurship. The improvement of knowledge and ability is the focus of College Students' attention. Therefore, the school should be carried out on the students to guide the students to help students understand the process of entrepreneurship, enhance the entrepreneurial ability. To solve the difficult employment of college students, in addition to cultivate their correct employment concept, as there is the ability to cultivate their own business. The entrepreneurship education curriculum for the entrepreneurs to light up a beacon, to find a way forward, to develop the students' spirit of practice, explore the spirit and adventure, but also to enhance their ability to stress and psychological quality. Because of our country's pioneering education starts late, therefore, should look for the education pattern which suits our country national condition, the step by step, can really help the entrepreneur. Let the idea of entrepreneurship into reality, not a moment of impulse.

\section{The construction of the curriculum system of entrepreneurship education in the perspective of general education}

Transformation of personnel training program. General education and entrepreneurship education curriculum system of the perfect combination, not only in order to allow students to succeed in business, but also in order to let the students can fully develop. Let the entrepreneurship education curriculum throughout the professional education, quality education and employment education, guide students to learn professional knowledge, correct attitude, pay attention to the development of the professional dynamics, and the creation of entrepreneurial education and guidance courses, so that students really feel the process of entrepreneurship. Twenty-first Century the most valuable is the talent, is a multi - directional professional conversion ability, which requires the transformation of talent training mode, not only to have a theoretical knowledge as a foundation, but also need to have practice to help students better understand the professional knowledge learned. Practice of entrepreneurship education courses to help students understand, understand the business process, and the need to support the business, so that the students know their own lack of knowledge, and then try to make up for the initiative to change the passive employment for the initiative to change their employment ideas, stimulate the enthusiasm of the students, and promote the development of innovative society. Entrepreneurship education needs not only the theory, but also abundant practice, practice. Innovation is the core of entrepreneurship. Therefore, colleges and universities should combined with different professional of different courses, let different professional can let a hundred flowers blossom, for our country and our society to develop a comprehensive. In order to improve their own learning, self sublimation, and not seek high official positions and riches means. We should correct the attitude of learning, so that we can now learn to serve our future, not only to enrich our knowledge, but also to help us. The purpose of a clear purpose, clear business expectations.

Pay attention to and improve the course construction. As a result of our country about the system is still very imperfect, so in the university period need to help students through the course of education and practice to find suitable for their own future path. During the university to set up and career planning related courses, so that each student can deepen the understanding of the self and a clear plan for the future of life, and understand the current employment situation and the type of talent, can fully understand the relationship between the self and their own development, not in order to ease the employment pressure and will start as the ultimate goal, should focus on social development direction to strengthen the study of professional courses, as well as their own personality development, rational choice. Now students greatly, although the perception of things is strong, independent learning ability is also very strong, thinking, active, energetic, but most of the students has not formed independent personality, the lack of a sense of responsibility, Yangaoshoudi, ambitious, like an armchair strategist, many entrepreneurial ideas are not feasible, poor psychological endurance, difficulty is back, and the lack of professional experience, interpersonal relationship etc., these have become the obstacles to the business, therefore, should be opened entrepreneurship 
practice class, let the students to experience. Set up the design contest, encourage students to participate in, the specific implementation of the program written down, and then by the guidance of the teacher assessment, select the best, feasible design, to help students start business, and guide students to design programs, guide them to find out the shortage and reform program to help students accumulate experience, improve their entrepreneurial ability. Theory is the practice of the support point, there is no theoretical support, it will become too weak, weak, so, the high quality of the teachers is the key to the success of the business. In the course of the students learning, the teacher also needs to continue to learn, to be able to really help the students in the process of teaching. The curriculum should be targeted, such as a strong willingness to start a number of entrepreneurial, innovative ability, and potential students, schools should focus on training, to help them improve the basic knowledge, skills, training their practical ability to strengthen the students' entrepreneurial guidance. To make the students become the dominant curriculum, can take the initiative to learn, and not just listen to the teacher, the most important is to be able to contact the actual theory, will learn the real use of knowledge to practice. For example, situational teaching, let students get knowledge in the instance, so in the future to similar problems can be solved handy, effortless, can stimulate students learning interest.

\section{Conclusion}

From the perspective of general education, entrepreneurship education curriculum is an indispensable part in the process of social development, it needs to combine with the needs of society, with the times, constantly adjust, to find a suitable way for development. For college students' entrepreneurial services, For the growth of entrepreneurs and entrepreneurs to provide a comfortable bed, so that entrepreneurs to promote scientific and technological progress, driven by employment, promote social progress, driven by the progress of the country. To create more jobs and employment opportunities for the society, To ease the severe employment situation in china. Merging of liberal education and shipping education, let originally single, narrow, rigid thought gradually rich, active, speculation on innovation, ways of thinking, let students to open the door to the idea of, good at finding opportunities, dare to innovate.

This paper is one of the research results of the "Jiangxi Province Education scientific planning project--"Entrepreneurial teaching material research and development of a curriculum"(NO. Jxjg-12-13-5 ).

\section{Referencs}

[1] Z.Y. Lei. General education and the cultivation of innovative talents of. science Herald, 2012, (9).

[2] Sun Haitao, Li Dong, Wang Wei. Thinking about the general education in University in China. Guizhou Social Sciences, 2009, (7).

[3] Huang Zhaoxin et al. The strategic choice for the transformation and development of entrepreneurship education in Colleges and universities. education research, 2012, (12).

[4] Y.C. Shi. Research on the development of entrepreneurship education in Colleges and universities in China for ten years (4),. China

[5] Cao Dahong ability and competency. The job occupation of Jiangsu higher education, 2012, (6). 